\title{
The Failures of Neoliberal Food Security and the Food Sovereignty Alternative
}

\author{
Laura Dawn Friesen*
}

\begin{abstract}
Nearly one billion people suffer from hunger worldwide. This issue has been a central concern for the international community, with national governments, non-governmental organizations, and international organizations seeking solutions. The dominant response to the issue of hunger has largely centered around the concept of food security which emerged within a context dominated by neoliberal ideology. This Neoliberal Food Security approach has focused on expanding global food production and incorporating farmers into global food markets. Yet, despite decades of programs and initiatives, hunger remains a daunting problem. Food Sovereignty has been offered as an alternative approach, challenging the assumptions and conceptualizations which underpin Neoliberal Food Security and seeking to alter the structures and unequal power relations inherent in the current global food system. This paper asserts that because Neoliberal Food Security fails to challenge the structures and inequalities which perpetuate hunger, it is an insufficient method for addressing the problem. In contrast, Food Sovereignty objects to the theories and practices of neoliberalism, thereby offering a radical alternative approach.
\end{abstract}

Keywords: Hunger; Food sovereignty; Food security; Neoliberalism

According to the International Fund for Agricultural Development (IFAD) there are as many as 925 million hungry people in the world today. This situation exists despite the fact that there is more than enough food produced globally to feed the world's population. This problem has been a central issue for the international community. Eliminating hunger has been included in the United Nations' (UN) Millennium Development Goals (MDGs) and Sustainable Development Goals (SDGs), and has been addressed by Non-Governmental Organizations (NGOs), national governments, and numerous international organizations.

The dominant response to hunger has centered on the concept of food security, defined as "when all people at all times have access to sufficient, safe, nutritious food to maintain a healthy and active life." Emerging within a global structure dominated by neoliberal ideology, this approach is deeply rooted in the narratives, assumptions, and dominant discourses of neoliberalism. This model, however, has failed to solve the problem. Food Sovereignty, defined as "the right of peoples to healthy and culturally appropriate food produced through ecologically sound and sustainable methods, and their right to define their own food and agriculture systems," has emerged as an alternative path to ending hunger.

This paper examines and critiques the Neoliberal Food Security (NFS) approach, and assesses how and why Food Sovereignty (FS) offers a viable alternative. Because Neoliberal Food Security fails to challenge the structures and inequalities that perpetuate hunger, it is an insufficient

\footnotetext{
*BA, Hon. International Studies, Department of Political Studies

Correspondence: Idf984@mail.usask.ca
}

University of Saskatchewan Undergraduate Research Journal

Volume 4, Issue 1, 2017 
method for addressing the problem. In contrast, Food Sovereignty objects to the theories and practices of neoliberalism, thereby offering a radical alternative approach.

Using a literature review, this paper will begin with a historical background of the global food regime and an overview of the failures of NFS policies and practices to provide context and to show how the current structures are problematic. It will then move on to an assessment of the core philosophies and principles that underlie both NFS and FS to demonstrate the fundamental differences between the two. This will be followed by a comparison of how NFS and FS respectively address two areas of contention within the global food system, agriculture and trade, to illustrate how these philosophies are manifest on a more practical level. The concluding remarks will include some future projections in relation to this issue.

\section{Historical Background}

To help organize the history of the world food system, Philip McMichael has used a global food regimes framework. This looks at the structures, characteristics and outcomes of major food regimes that have dominated on a global level in different periods. ${ }^{1}$ Recent history can be divided into three broad regimes. The first is the Post-War regime, which was in place from the 1940 s until the $1970 .^{2}$ The second is the neoliberal regime, which lasted from the 1970 s to $2008 .{ }^{3}$ Since 2008 , the neoliberal regime has largely continued to dominate, however, with some important shifts. ${ }^{4}$ These regimes are divided by the global food crises of 1972-73 and of 2007-08, which forced a reassessment of current practices and policies and their ability to feed the world population. ${ }^{5} \mathrm{~A}$ brief overview of these global food regimes provides historical context to the current situation and shows that many of the dominant ideas today have been continually reinforced for decades, despite their ineffectiveness.

${ }^{1}$ Philip McMichael, "The World Food Crisis in Historical Perspective," in Agriculture and Food in Crisis: Conflict, Resistance, and Renewal, eds. Fred Magdoff and Brian Tokar (New York: Monthly Review Press, 2010), 57.

${ }^{2}$ Ibid.

${ }^{3}$ Ibid.

${ }^{4}$ Ibid.

${ }^{5}$ Fairbairn, "Framing Resistance," 21.
1940 s to 1970 s

The end of World War II brought a new era in international relations. With the formation of the UN and the Bretton Woods institutions, coordination of policies and practices at the international level reached new heights. ${ }^{6}$ It was also during this period that the development project emerged, guided by Rostow's modernization theory, which sought national economic growth through industrialization. ${ }^{7}$ As part of this line of thinking, small-scale and peasant farmers were largely viewed as a hindrance to development and, instead, the modernization of agriculture through the use of Western science and technology was seen as necessary. ${ }^{8}$ Focus was put on cash crop production for export as a way to raise the foreign currency needed to finance development projects. ${ }^{9}$

At this time, hunger was largely addressed through aid. ${ }^{10}$ A large surplus of grain in the United States, which threatened to collapse domestic prices, was distributed as food aid in the South. ${ }^{11}$ Not only did this help to solve the domestic surplus problem, it was also seen as part of the moral obligation to assist other countries, and was useful in gaining allies in the Cold War context. ${ }^{12}$ The implications of this emphasis on food aid included changing diets, undermining local production, and creating dependency. ${ }^{13}$ In addition, large-scale agriculture and development projects caused the dispossession and displacement of peasant farmers. ${ }^{14} \mathrm{~A}$ world food crisis in 1972-73 brought an end to this global food regime and ushered in an era in which neoliberalism would come to dominate. ${ }^{15}$

${ }^{6}$ McMichael, "Historical Perspective," 57.

${ }^{7}$ Fairbairn, "Framing Resistance," 21.

$8 \mathrm{Jim}$ Handy and Carla Fehr, "'Drawing Forth the Force that Slumbered in Peasants' Arms": The Economist, High Agriculture, \& Selling Capitalism," in Food Sovereignty: Reconnecting Food, Nature and Community, eds. Hannah Wittman, Annette Desmarais, and Nettie Wiebe (Black Point: Fernwood Publishing, 2010), 58.

9 McMichael, "Historical Perspective," 58.

10 Ibid.

${ }^{11}$ Fairbairn, "Framing Resistance," 21.

12 Ibid.

13 William D. Shanbacher, The Politics of Food: The Global Conflict Between Food Security and Food Sovereignty (Santa Barbara: Praeger, 2010), 33.

14 McMichael, "Historical Perspective," 58.

15 Fairbairn, "Framing Resistance," 21. 
1970s to 2008

The food crisis of 1973-74 caused many to reassess the global food system. It spurred a meeting of world leaders at the World Food Conference in Rome in 1974 to address the problem. ${ }^{16}$ One of the major outcomes of the Conference was the idea that hunger was not solely the result of production failures from events such as drought, but was also directly tied to poverty. ${ }^{17}$ The concept of food security rose to prominence at the global level, defined as an adequate supply of basic foodstuffs. ${ }^{18}$ This food security narrative was taken up by the UN, the World Bank, and other organisations that focused on ending hunger - such as IFAD, which was created in $1977 .{ }^{19}$

The policies and practices of this period reflect these new approaches to food and hunger. Priority was still given to increasing production through technological innovation. ${ }^{20}$ However, whereas in the previous food regime an increase in production was seen as necessary for national economic growth through industrialization, the focus now shifted to eradicating rural poverty at the household level in order for farmers to increase their purchasing power. ${ }^{21}$ The dominant ideas of this period are epitomized in the Green Revolution, which focused on increasing production through mechanization, the application of chemical inputs such as fertilisers and pesticides, and the use of commercial seed varieties meant to increase yields of staple crops. ${ }^{22}$ A continual rise of neoliberal ideology created the context in which this was occurring.

16 Lucy Jarosz, "Comparing Food Security and Food Sovereignty Discourses," Dialogues in Human Geography 4, no. 2 (2014): 171, accessed February 1, 2016, doi: $10.1177 / 2043820614537161$

17 "Who We Are," IFAD, accessed March 3, 2016, https://www.ifad.org/who/overview.

18 Raj Patel, "What Does Food Sovereignty Look Like?" in Food Sovereignty: Reconnecting Food, Nature and Community, eds. Hannah Wittman, Annette Desmarais, and Nettie Wiebe (Black Point: Fernwood Publishing, 2010), 187.

${ }^{19}$ Schanbacher, Politics of Food, 5.

20 Jarosz, "Comparing," 171.

${ }^{21}$ Ibid.

22 Hannah Wittman, "Reconnecting Agriculture \& the Environment: Food Sovereignty \& the Agrarian Basis of Ecological Citizenship," in Food Sovereignty: Reconnecting Food, Nature and Community, eds. Hannah Wittman, Annette Desmarais, and Nettie Wiebe (Black Point: Fernwood Publishing, 2010), 93.
During this period, neoliberalism came to dominate both nation-states and international organisations. ${ }^{23}$ The neoliberal doctrines of privatisation, liberalisation, and deregulation increasingly were applied to food and agricultural markets under the assumption that this would aid in reducing hunger. ${ }^{24}$ Structural Adjustment Programs (SAPs) spread these ideas and policies to developing countries that were then under the obligation to open up their economies to trade and capital flows, as well as to reduce government spending by ending support programs. ${ }^{25}$ The formation of the World Trade Organization (WTO) at the end of the Uruguay Round in 1995 further entrenched these neoliberal policies. ${ }^{26}$ Specifically, the Agreement on Agriculture (AoA), the Agreement on TradeRelated Investment Measures (TRIMS), and the Agreement on Trade-Related Aspects of Intellectual Property Rights (TRIPS) came into effect and sought to reduce barriers to trade in agricultural goods; open up industries to foreign investment; and create rights for patent holders, respectively. ${ }^{27}$ This helped facilitate the emergence of large agribusiness firms and these transnational corporations (TNCs) became active in seed, chemical, and land markets. ${ }^{28}$ These shifts had a number of implications for global food and agriculture.

The impact of this period was felt both environmentally and socially. Green Revolution practices had succeeded in raising yields of certain crops, however, they also resulted in soil degradation, water pollution, decreased biodiversity and a concurrent increase in vulnerability to pests and diseases. ${ }^{29}$ The Green Revolution also left farmers dependent on external and expensive inputs, which resulted in high levels of debt. ${ }^{30}$ Control over these input markets was concentrated in the hands of

23 Fairbairn, "Framing Resistance," 25.
24 Jarosz, "Comparing," 171.
25 Walden Bello and Maria Baviera, “Capitalist Agriculture, the Food Price Crisis \& Peasant Resistance," in Food Sovereignty: Reconnecting Food, Nature and Community, eds. Hannah Wittman, Annette Desmarais, and Nettie Wiebe (Black Point: Fernwood Publishing, 2010), 66.

${ }^{26} \mathrm{Kim}$ Burnett and Sophia Murphy, "What Place for International Trade in Food Sovereignty?" The Journal of Peasant Studies 41, no.6 (2014): 1075, accessed February 5, 2016, doi: 10.1080/03066150.2013.876995.

27 Ibid.

28 Shanbacher, Politics of Food, 50.

${ }^{29}$ Wittman, "Reconnecting," 93.

30 Ibid. 
TNCs. ${ }^{31}$ SAPs had effectively reduced the sovereignty of national governments and thus their ability to determine the structure of their own food systems or to support local food production. ${ }^{32}$ As in 1972-73, a world food crisis in 200708 caused a reassessment of the global food system. ${ }^{33}$

\section{8 to the Present}

A number of factors contributed to the 2007-08 crisis. Developing countries had become highly dependent on imported food products as local production had been displaced by cheap imports from the North and had shifted to cash crop production for export as part of rural development projects. ${ }^{34}$ In addition to this, speculation in commodity futures, which increased following the economic crash in the United States, caused instability and price fluctuations in global food markets. 35 Importdependent countries were left vulnerable to price changes and neoliberal reforms had left few government support programs in place, meaning that when prices rose the impact was felt at both ends of the food chain. ${ }^{36}$ Farmers continued to receive low prices for their goods and were forced to pay ever-increasing prices for inputs, while consumers paid much more for basic foodstuffs. ${ }^{37}$ However, the TNCs, who had come to dominate every aspect of the food chain, experienced record profits at a time when nearly one billion people went hungry. ${ }^{38}$

The reaction to the 2008 crisis was to redouble existing efforts under the assumption that current policies and practices only needed to be implemented in a more

${ }^{31}$ Shanbacher, Politics of Food, 50.

32 Ibid., 39.

${ }^{33}$ McMichael, "Historical Perspective," 62.

${ }^{34}$ Fred Magdoff and Brian Tokar, "Agriculture and Food in Crisis: An Overview," in Agriculture and Food in Crisis: Conflict, Resistance, and Renewal, eds. Fred Magdoff and Brian Tokar (New York: Monthly Review Press, 2010), 10.

35 Ibid., 11.

36 Meleiza Figueroa, "Food Sovereignty in Everyday Life: Toward a People-centered Approach to Food Systems," in Globalizations 12, no. 4 (2015): 505, accessed February 1, 2016, doi:10.1080/14747731.2015.1005966.

37 Peter Rosset, "Fixing Our Global Food System: Food Sovereignty and Redistributive Land Reform," in Agriculture and Food in Crisis: Conflict, Resistance, and Renewal, eds. Fred Magdoff and Brian Tokar (New York: Monthly Review Press, 2010), 189.

38 Ibid. effective way. ${ }^{39}$ Today, the global food system and the NFS approach continues to be dominated by large TNCs, who are increasingly concentrating power over land, seeds, chemical inputs, genetic resources, trade, processing, and retailing. $4^{40}$ This is facilitated by a continued push for trade liberalisation among dominant global actors. ${ }^{41}$ Organisations such as the World Bank have called for an expansion of industrial agricultural practices in an attempt at increasing production while simultaneously incorporating farmers into global value chains to increase their incomes. ${ }^{42}$

In addition to this, the crisis in 2008 pushed many to look for food security and profits through acquiring land in developing countries, particularly in Africa. ${ }^{43}$ In this "new scramble for Africa," 44 as of 2010 , some 40 million hectares of land had come under foreign ownership or were in the process of negotiation. ${ }^{45}$ These purchases are being made by national governments, private companies, and financial institutions, and have furthered the dispossession of smallscale and peasant farmers. ${ }^{46}$

McMichael states that the current food regime is characterised by both a trade-centered assault, under which dumping of agricultural goods in developing countries undermines local production; and an investment-centered assault, under which control of land is continually lost to

39 GRAIN, "The New Farm Owners: Corporate Investors and the Control of Overseas Farmland," in Agriculture and Food in Crisis: Conflict, Resistance, and Renewal, eds. Fred Magdoff and Brian Tokar (New York: Monthly Review Press, 2010), 145.

${ }^{40}$ Laura T. Raynolds and John Wilkinson, "Fair Trade in the Agriculture and Food Sector: Analytical Dimensions," in Fair Trade: The Challenge of Transforming Globalization, eds. Laura T. Raynolds, et al. (New York: Routledge, 2007), 35.

${ }^{41}$ Schanbacher, Politics of Food, 38.

42 Philip McMichael, "The Land Question in the Food Sovereignty Project," in Globalizations 12, no. 4 (2015): 435, doi:10.1080/14747731.2014.971615.

43 Jarosz, "Comparing," 169.

44 Ibid.

45 GRAIN, "The New Farm Owners," 140.

${ }^{46}$ Sarturnino M. Borras and Jennifer C. Franco, "Food Sovereignty \& Redistributive Land Policies: Exploring the Linkage, Identifying Challenges," in Food Sovereignty: Reconnecting Food, Nature and Community, eds. Hannah Wittman, Annette Desmarais, and Nettie Wiebe (Black Point: Fernwood Publishing, 2010), 107. 
outside interests. 47 In addition to this, the prices of food and agricultural inputs have remained high since the 2008 crisis and financial speculation continues to result in price volatility..$^{48}$ There have been three spikes in food prices since 2008,49 leaving countries that continue to rely heavily on food imports vulnerable. ${ }^{50}$ The food system is also facing increasing pressure from climate change, environmental degradation, and competition with non-food production, such as for biofuels and animal feed. ${ }^{11}$ Within this context of instability, corporate control, and environmental vulnerability, alternatives to this neoliberal model are being proposed.

A move to reinforce NFS following the 2007-08 crisis was not the only reaction. Many also began to question the viability of the existing global food system..$^{52}$ For some, the crisis was evidence that the current model was not only failing to address hunger, but was actively perpetuating it. 53 This reaction is embodied within the FS movement. FS is a concept, a discourse, and a set of practices which challenge neoliberal ideology, and thus the NFS approach. ${ }^{54}$ Through a reconceptualisation of food and hunger, ${ }^{55}$ FS offers a viable solution that is rooted in drastically different values and practices from the current system. This is a revolutionary approach that seeks structural change, rather than seeking reforms which leave in place the power

${ }^{47}$ McMichael, "The Land Question," 436.

48 Jarosz, "Comparing," 168, 171.

49 Annie Shattuck, Christina M. Schiavoni and Zoe VanGelder, "Translating the Politics of Food Sovereignty: Digging into Contradictions, Uncovering New Dimensions," in Globalizations 12, no. 4 (2015): 423, accessed February 1, 2016, doi:10.1080/14747731.2015.1041243.

${ }^{50}$ Magdoff and Tokar, "Agriculture and Food," 14.

51 Hannah Wittman, Annette Desmarais and Nettie Wiebe, "The Origins and Potential of Food Sovereignty," in Food Sovereignty: Reconnecting Food, Nature and Community, eds. Hannah Wittman, Annette Desmarais and Nettie Wiebe (Black Point: Fernwood Publishing, 2010), 10.

52 McMichael, "The Land Question," 445.

53 Wittman, Desmarais and Wiebe, "The Origins and Potential," 1.

54 Christopher M. Bacon, "Food Sovereignty, Food Security and Fair Trade: The Case of an Influential Nicaraguan Smallholder Cooperative," in Third World Quarterly 36 no. 3 (2015): 474, accessed February 5, 2016, doi:10.1080/01436597.2015.1002991.

55 Figueroa, “Food Sovereignty," 502. relations which perpetuate hunger and poverty. ${ }^{56}$ An assessment of the core philosophies and values of both NFS and FS will emphasize the fundamental differences between the two.

\section{Comparative Analysis}

\section{Philosophy of Neoliberal Food Security (NFS)}

According to Madeleine Fairbairn, food security "originated in the corridors of global power." Thus, the concept is firmly rooted in Western and neoliberal ideology and incorporates the assumptions and narratives of these worldviews into its core principles and approaches. Some of these narratives can be tied back to Malthusian ideas of population growth and limited resources, which is reflected in the focus on increasing production within NFS. For example, the websites of the FAO, the World Bank, and IFAD all strongly emphasize how global food production will have to increase $50-70 \%$ by 2050 to feed a projected 9 billion people. A Western faith in science and technology, combined with myths regarding the backwardness and unproductiveness of peasant agriculture, figure prominently in NFS. Jim Handy and Carla Fehr connect these ideas to 18th-century England where capitalists, politicians, and liberal economists promoted the idea that the only way forward was ending peasant agriculture and embracing industrial methods of production. Thus, it is clear that NFS is a product of a very specific worldview and is subject to neoliberal assumptions and discourses.

Within neoliberalism, there is a tendency to depoliticize issues by presenting them as natural, technical problems. In removing considerations of power relations, inequality, or inherent structural problems, the focus shifts to pragmatic, technical solutions. This is manifest through the NFS approach in both the conceptions of food and hunger as well as their proposed solutions. The problem of hunger, within neoliberal ideology, is considered a problem of supply and demand. If one is unable to obtain adequate food it is assumed to be from a failure either of production or because of a financial inability to purchase sufficient food in the market. Drought, floods and other natural disasters are responsible for production failures, while poverty causes a lack of purchasing power. The answer then becomes two fold. First is increasing production and expanding trade in order to ensure an adequate supply of food. The second is ending poverty through economic development.

56 Shattuck, Schiavoni and VanGelder, "Translating the Politics," 429. 
The conceptualisation of food is also important here. Within NFS, food is a commodity that holds only caloric and economic value. The level of food security is measured by the amount of kilocalories available to people. The purpose of food becomes simply to fuel the body and its value becomes the number of calories it holds. In terms of its economic value, food is a material good to be used for economic development. Selling food in global markets is seen as a pathway for increasing incomes and strengthening the purchasing power of producers, who will then be able to purchase food. This quantifiable, technical conception of food strips it of its cultural, social, and environmental value as it is reduced to calories and profits. Hunger is also reduced to a technical problem that requires increasing the calorie intake and incomes of those that experience hunger. There is no consideration of how power dynamics or inequitable social relations impacts one's ability to obtain adequate food, thus, depoliticising food and hunger. In contrast to this, FS has a vastly different conceptualisation of food and hunger.

\section{Philosophy of Food Sovereignty (FS)}

FS emerged as a reaction to the failures of the NFS approach. The farmers and peasants who had continually lost support programs and control over their land and other productive resources under neoliberal policies began to demand alternatives. The concept of food sovereignty was first put forward by La Vía Campesina, a transnational peasant organization, at the 1996 World Food Summit. FS emerged from among the oppressed and is backed by a worldview much different from that which dominates NFS. The fundamental principles of FS include the right to food, the right of each nation and/or peoples to define their agriculture and food policies, production for local markets, agrarian reform, exclusion of agriculture and food products from free trade, and the use of sustainable farming practices. Central values include social justice, selfdetermination, equality, dignity, sufficiency, communal ownership and rights, and of course, sovereignty. These quite obviously contrast with neoliberal values of individualism, production solely for profit, and endless economic growth.

FS calls for a fundamental reconceptualisation of food. It recognizes that social connections are an inherent part of producing and consuming food, and that food is a material through which social relations are transmitted. Within FS, food takes on cultural, social, political, and environmental importance and holds value beyond profits and calories. This holistic view is also used in the conceptualisation of hunger. The causes of hunger are seen to be rooted in social relations in which power, exclusion, and inequality bring about unequal access to and control over productive resources and food systems. By reincorporating the power dynamic into the issue of hunger, FS effectively politicises the issue and forces the consideration of how the structures of the current neoliberal system reinforce and perpetuate a situation in which some people have more than enough while others starve and in which TNCs make record profits while peasant farmers remain impoverished.

This reconceptualisation of food and hunger results in a vastly different approach. FS uses the language of human rights to insist that access to and control over food and productive resources, such as land, seeds, and water, is a fundamental human right. This reframes the current global food system, in which corporations increasingly control and own these aspects of food production and consumption, as a violation of human rights. FS also rejects the NFS focus on individual or household level calorie intake and instead considers food security to be when individuals, communities, and nations have healthy and culturally appropriate food, as well as the ability to define their own food systems. This is to be achieved through decentralised and democratic control over food systems, with "multiple sovereignties" allowing for agency and decision-making power at various and overlapping levels to ensure effective control and participation for all. In these ways, food sovereignty counters the centralised, economic-focused, technical approaches found within NFS. An analysis of the more practical prescriptions offered by NFS and FS in relation to agriculture and trade reveals how these different conceptualisations of food and hunger manifest themselves in practice.

\section{Agriculture}

Agriculture, obviously, plays a central role in addressing hunger. However, the NFS and FS approaches have vastly different ideas regarding the role of agriculture and the way it should be undertaken. As mentioned, neoliberalism has a tendency to view everything in solely economic terms and this applies to agriculture as well. First, NFS takes an economic view of the productive factors of agriculture. Land, seeds, water, and other natural resources are seen as forms of capital whose function is to act as inputs in a process of production for profit. These resources have no social or cultural value other than their ability to produce a marketable good. Secondly, the food that is the "output" of agriculture also takes on only economic dimensions as it is viewed as a commodity to be sold and a mechanism for increasing incomes. Agriculture becomes a pathway to development, not necessarily valuable in itself, but a tool to achieve the neoliberal goal of economic growth.

The agricultural prescriptions and practices of NFS reflect this economic conception of nature and food. The goal is to produce and distribute food in the most efficient and cheapest way possible. The focus when measuring agricultural efficiency is the total quantitative yields minus 
the amount of inputs required to achieve this. The social, cultural, and environmental costs of agriculture are considered "externalities." Thus, the displacement of workers by machinery, the loss of land through consolidation, the pollution caused by heavy chemical and fossil fuel use, and the loss of biodiversity through monocultures are not incorporated into calculations of efficiency.

Tied to Industrial Revolution ideas of simplification, specialization, and separation, as well as human mastery of nature, agriculture within NFS has focused on industrial agriculture. This approach centers on monoculture, mechanisation, genetic modification, and heavy use of chemical inputs such as fertilisers and pesticides in an attempt at achieving ever-increasing yields. Central to NFS practices is "improving" the agricultural methods of small farmers in order to increase their output. The underlying idea here is that small-scale farmers have the potential to become entrepreneurs if they are given the technology and knowledge of modern agriculture, but that their production is not valuable until it enters the market.

FS has a drastically different approach to agriculture. The concept of agrarian citizenship and the practice of agroecology embody the values and principles of the FS approach. Agriculture is seen as much more than simply producing commodities or as a path to economic growth. Instead, agriculture plays a role in the environment, in the economy, in society, and in an individual's health through diet and nutrition. FS recognises that, for many, farming is not simply a job but a way of life, and argues that production should focus on fulfilling social needs rather than endless expansion in pursuit of profit. This is based on a reconceptualisation of the relationship between society and nature, which is reflected in the concept of agrarian citizenship. Under this new 'ecological rationality,' producers have a right to land but also a responsibility for maintaining the environment and for contributing to social wellbeing. This alternative conception of the human-nature relationship is reflected in agroecology as well.

Agroecology has become a pillar of FS as the practical method of building this new reality. Agroecology is a model of farming, which seeks to achieve production through working with nature, as opposed to dominating over it. It centers on studying ecosystems and understanding complex natural processes in order to incorporate them into farming methods. For example, agroforestry techniques, intercropping, and integrated pest management are a few of the strategies used to help eliminate the need for chemical inputs. This model precludes a one-size-fits-all approach to be applied across diverse regions, and instead looks to general principles that can be translated and adapted to local conditions. Intimate local knowledge is considered essential to implementing successful systems, and value is placed on traditional knowledge, which is blended with scientific knowledge. This approach also requires that productive resources remain under the control of producers. Farmers retaining, or obtaining, control over land, seeds, and water is central to FS. This autonomy allows farmers to become stewards of the environment as they can control the inputs and methods used. Through knowledge-sharing networks such as the Campesino-a-Campesino movement, farmers are able to learn about and adopt methods that can both increase production and reduce the negative environmental impact of agriculture.

There are many benefits to agroecology. Farmers are not dependent upon seed and chemical companies for their inputs, biodiversity and nutrient cycles are maintained, diets are diversified, the separation between production and consumption is reduced, and ecosystems become more resilient and less vulnerable to climate change. In addition to this, agroecology methods have been proven to produce food reliably and with higher yields than industrial agriculture when considering total output of all goods produced. Social benefits of this approach include empowerment and autonomy that come with having control over food systems, better health of both people and ecosystems, and local employment.

In a 2009 report from the International Assessment of Agricultural Knowledge, Science and Technology for Development (IAASTD) - which consists of scientists and policy makers from numerous organizations, including the FAO and the World Bank - it was argued that small-scale, low-input agriculture and food sovereignty concepts were preferable to current industrial agricultural practices, and that these concepts should be embraced going forward. The report was heavily criticised by the national governments of Canada, Australia, and the United States, as well as by TNCs. In addition, the World Bank and the FAO have failed to include these findings in any of their major publications or to refer to them at subsequent food summits. However, this demonstrates that the agricultural practices embraced by the FS movement are recognised as beneficial and capable of feeding the world and that many of the narratives that reinforce the NFS reliance on industrial agriculture are not the scientific "truths" they are portrayed to be.

\section{Trade}

Trade is another issue central to the conflict between NFS and FS approaches. Free trade is a key element in NFS policies. This is based on the neoliberal faith in free market principles and the idea that trade will inevitably bring about benefits for all by increasing production through comparative advantage and increasing incomes by selling on the global market. This is reflected in the NFS policies of organisations such as the World Bank, the FAO, and IFAD who continue to emphasize the 
importance of incorporating farmers into global markets in order for them to be able to "realise their potential" as producers. Again, this is built on the assumption that agriculture and food are tools of economic growth.

Unfortunately, the inclusion of agriculture in WTO rules and free trade agreements has failed to benefit the majority of producers. This is partly because not all countries have applied the same rules to their agricultural goods as others. North American and European countries continue to heavily subsidize agriculture while developing countries often do not have the financial or legal ability to do the same. The outcome of this has been dumping of cheap agricultural goods from the North, which flood the market in developing countries, push out local production, and create a dependency on imported food. As mentioned, this dependency leaves these countries vulnerable to price fluctuations and has been a central factor to food crises. Liberalisation of trade also promotes the production of export commodities such as coffee, chocolate, fruit and vegetables, and grains for animal feed and biofuels, all of which are most often consumed in the North. Overall, trade in agricultural goods has done little to increase food availability for the poor and hungry, to empower local producers, or to improve the quality of life for the majority of farmers.

FS has a divergent view of trade. It does not see trade as inherently bad, however, it critiques the doctrine of free trade and the structure of trade as it stands now. FS sees the current global trade system as one that benefits only large agribusiness corporations and poses a threat to small-scale agricultural producers. They see the unequal power relations inherent in the current system as facilitating neocolonial control over the food, land, and agriculture sectors of developing countries. Instead, FS emphasizes local production for local consumption as the primary focus and trade as only secondary to this. FS calls for trade that is transparent, just, and serves the collective society. Trade is seen as useful in cases where domestic production does not meet demand or does not facilitate a diverse enough diet; where surplus is great enough to be exported; where controls on trade are readily available to offer protection to local producers; and where consumer rights are protected.

While FS calls for a fairer trade to be realized, it critiques the current fair trade movement as an insufficient challenge to the dominant neoliberal model. It is argued that fair trade does not challenge monoculture practices, it leaves producers dependent upon external markets, and it can still displace food production in favour of high-income goods. Fair trade certification schemes can be exclusionary and are vulnerable to corporate takeover. Essentially, FS argues that a more radical approach is required and that for trade to contribute to the reduction of hunger it must be structured in completely different ways. The current approach, and even alternatives such as fair trade, serve only to reinforce the neoliberal structures and continue to facilitate the dispossession and further impoverishment of small-scale producers.

\section{Conclusion}

FS has made significant progress since it was first proposed by La Vía Campesina in 1996. Vía Campesina has gained recognition at the international level, both by growing their peasant movement and by seeking partnerships with NGOs and UN bodies such as the FAO. It is now a member of the FAO's Commission for Food Security (CFS) and promotes the FS platform through this channel. The national governments of Venezuela, Ecuador, Nepal, Bolivia, Nicaragua, Mali, and Senegal have incorporated food sovereignty into their constitutions and other legislation. At the local level, numerous peasant and indigenous movements have embraced and continue to reinforce the philosophies and practices of the FS approach. In these ways, FS is gaining recognition and legitimacy as a viable alternative to the current system.

Despite these gains, there have been few significant structural changes in the global food regime. Neoliberalism continues to dominate among national governments, particularly in the North; within international organizations, such as the World Bank, the IMF, and the WTO; and within the agribusiness TNCs who profit from the system. The narratives of the NFS approach remain strong. Faith in free trade, industrial agriculture, and a fear of unhindered population growth reinforce the policies and programs that continue to focus primarily on increasing production through scientific methods and on incorporating farmers into global food chains. For the FS movement to make progress within this context, it must retain its revolutionary characteristic to avoid being appropriated into the neoliberal paradigm. This seems to be the case. For example, Vía Campesina withdrew from the Our World is Not for Sale coalition when it moved toward seeking reforms as opposed to a complete restructuring of the system, indicating that the FS movement is committed to radical change.

This paper has demonstrated that the dominant approach toward solving hunger at the global level has been rooted in Western and neoliberal conceptions of food, hunger, agriculture, and trade, and that these NFS efforts have fallen short because they reinforce the unequal structures that have not only failed to address poverty and hunger, but also have actively promoted it. Clearly, any approach rooted in the fundamental philosophies of neoliberalism will be insufficient in addressing the problem and that a drastic reconceptualisation is necessary. This alternative approach is embodied in the FS movement, which seeks a world in which control over food and productive resources is upheld as a human right and in 
which social justice, equality, and self-determination allow for autonomy and food for everyone.

\section{Bibliography}

Altieri, Miguel A. "Agroecology, Small Farms, and Food Sovereignty." In Agriculture and Food in Crisis: Conflict, Resistance, and Renewal, edited by Fred Magdoff and Brian Tokar, 253-266. New York: Monthly Review Press, 2010.

---. "Scaling Up Agroecological Approaches for Food Sovereignty in Latin America." In Food Sovereignty: Reconnecting Food, Nature and Community, edited by Hannah Wittman, Annette Demarais, and Nettie Wiebe, 120-133. Black Point: Fernwood Publishing, 2010.

Bacon, Christopher M. "Food Sovereignty, Food Security and Fair Trade: The Case of an Influential Nicaraguan Smallholder Cooperative." Third World Quarterly 36, no.3 (2015): 469-488. Accessed February 5, 2016. doi:10.1080/01436597.2015.1002991.

Bello, Walden, and Maria Baviera. "Capitalist Agriculture, the Food Price Crisis \& Peasant Resistance." In Food Sovereignty: Reconnecting Food, Nature and Community, edited by Hannah Wittman, Annette Demarais, and Nettie Wiebe, 62-75. Black Point: Fernwood Publishing, 2010.

Borras, Saturnino M., and Jennifer C. Franco. "Food Sovereignty \& Redistributive Land Policies: Exploring the Linkage, Identifying Challenges." In Food Sovereignty: Reconnecting Food, Nature and Community, edited by Hannah Wittman, Annette Demarais, and Nettie Wiebe, 106-119. Black Point: Fernwood Publishing, 2010.

Burnett, Kim, and Sophia Murphy. "What Place for International Trade in Food Sovereignty? " The Journal of Peasant Studies 41, no. 6 (2014): 10651084. Accessed February 5, 2016. doi:10.1080/03066150.2013.876995.

Claeys, Priscilla. "Food Sovereignty and the Recognition of New Rights for Peasants at the UN: A Critical Overview of La Via Campesina's Rights Claims Over the Last 20 Years." Globalizations 12, no. (2015): 452-465. Accessed February 1, 2016. doi:10.1080/14747731.2014.957929.
Cohn, Avery, and Jonathan Cook. "Executive Summary." In Agroecology and the Struggle for Food Sovereignty in the Americas, edited by Avery Cohn, Jonathan Cook, Margarita Fernandez, Rebecca Reider, and Corrina Steward, xiii-xvii. Nottingham: Russell Press, 2006.

Fairbairn, Madeleine. "Framing Resistance: International Food Regimes \& the Roots of Food Sovereignty." In Food Sovereignty: Reconnecting Food, Nature and Community, edited by Hannah Wittman, Annette Desmarais, and Nettie Wiebe, 15-32. Black Point: Fernwood Publishing, 2010.

FAO. "Food Loss and Food Waste." Accessed March 2, 2016. http://www.fao.org/food-loss-and-foodwaste/en/.

-. "Seeds." Accessed March 5, 2016. http://www.fao.org/seeds/en/.

FAO, IFAD, and WFP. The State of Food Insecurity in the World 2015: Meeting the 2015 International Hunger Targets, Taking Stock of Uneven Progress. Rome: FAO, 2015. Accessed March 2, 2016. http://www.fao.org/3/a-i4646e.pdf

Figueroa, Meleiza. "Food Sovereignty in Everyday Life: Toward a People-centered Approach to Food Systems." Globalizations 12, no. 4 (2015): 498-512. Accessed February 1, 2016. doi:10.1080/14747731.2015.1005966.

Food Secure Canada. "What Is Food Sovereignty." Accessed March 5, 2016. http://foodsecurecanada.org/who-we-are/whatfood-sovereignty.

GRAIN. "The New Farm Owners: Corporate Investors and the Control of Overseas Farmland." In Agriculture and Food in Crisis: Conflict, Resistance, and Renewal, edited by Fred Magdoff and Brian Tokar, 139-153. New York: Monthly Review Press, 2010.

Handy, Jim, and Carla Fehr. "'Drawing Forth the Force that Slumbered in Peasants' Arms": The Economist, High Agriculture, \& Selling Capitalism." In Food Sovereignty: Reconnecting Food, Nature and Community, edited by Hannah Wittman, Annette Demarais, and Nettie Wiebe, 45-61. Black Point: Fernwood Publishing, 2010. 
IFAD. "Food Security Facts and Figures." Accessed March 2, 2016. https://www.ifad.org/topic/facts_figures/overview/ tags/food_and_nutrition_security.

-."The Future of World Food and Nutrition Security." Accessed March 2, 2016. https://www.ifad.org/en/topic/tags/food_and_nutri tion_security/1952762.

-. "Who We Are." Accessed March 3, 2016. https://www.ifad.org/who/overview.

Iles, Alastair, and Maywa Montenegro de Wit. "Sovereignty at What Scale? An Inquiry into Multiple Dimensions of Food Sovereignty." Globalizations 12, no. 4 (2015): 481-497. Accessed February 1, 2015. doi:10.1080/14747731.2014.957587.

Jarosz, Lucy. "Comparing Food Security and Food Sovereignty Discourses." Dialogues in Human Geography 4, no. 2 (2014): 168-181. Accessed February 1, 2016. doi:10.1177/2043820614537161.

Levins, Richard. "A Whole System View of Agriculture, People, and the Rest of Nature." In Agroecology and the Struggle for Food Sovereignty in the Americas, edited by Avery Cohn, Jonathan Cook, Margarita Fernandez, Rebecca Reider, and Corrina Steward, 34-49. Nottingham: Russell Press, 2006.

Magdoff, Fred, and Brian Tokar. "Agriculture and Food in Crisis: An Overview." In Agriculture and Food in Crisis: Conflict, Resistance, and Renewal, edited by Fred Magdoff and Brian Tokar, 9-30. New York: Monthly Review Press, 2010.

McAfee, Kathleen. "Sustainability and Social Justice in the Global Food System." In Agroecology and the Struggle for Food Sovereignty in the Americas, edited by Avery Cohn, Jonathan Cook, Margarita Fernandez, Rebecca Reider, and Corrina Steward, 1-15. Nottingham: Russell Press, 2006.

McMichael, Philip. "The Land Question in the Food Sovereignty Project." Globalizations 12, no. 4 (2015): 434-451. Accessed February 1, 2016. doi:10.1080/14747731.2014.971615 .

McMichael, Philip. "The World Food Crisis in Historical Perspective." In Agriculture and Food in Crisis: Conflict, Resistance, and Renewal, edited by Fred Magdoff and Brian Tokar, 51-67. New York: Monthly Review Press, 2010.
Patel, Raj. "What Does Food Sovereignty Look Like?" In Food Sovereignty: Reconnecting Food, Nature and Community, edited by Hannah Wittman, Annette Demarais, and Nettie Wiebe, 186-196. Black Point: Fernwood Publishing, 2010.

Pimbert, Michel, and M. Taghi Farvar. "Forward." In Agroecology and the Struggle for Food Sovereignty in the Americas, edited by Avery Cohn, Jonathan Cook, Margarita Fernandez, Rebecca Reider and Corrina Steward, viii-ix. Nottingham: Russel Press, 2006.

Pretty, Jules. "Can Ecological Agriculture Feed Nine Billion People?" Chap. 16 in Agriculture and Food in Crisis: Conflict, Resistance, and Renewal, edited by Fred Magdoff and Brian Tokar, 283-298. New York: Monthly Review Press, 2010.

Raynolds, Laura T., and John Wilkinson. "Fair Trade in the Agriculture and Food Sector: Analytical Dimensions." In Fair Trade: The Challenge of Transforming Globalization, edited by Laura T. Raynolds, Douglas L. Murray, and John Wilkinson, 33-48. New York: Routledge, 2007.

Rosset, Peter. "Fixing Our Global Food System: Food Sovereignty and Redistributive Land Reform." In Agriculture and Food in Crisis: Conflict, Resistance, and Renewal, edited by Fred Magdoff and Brian Tokar, 189-205. New York: Monthly Review Press, 2010.

Schanbacher, William D. The Politics of Food: The Global Conflict Between Food Security and Food Sovereignty. Santa Barbara: Praeger, 2010.

Shattuck, Annie, Christina M. Schiavoni and Zoe VanGelder. "Translating the Politics of Food Sovereignty: Digging into Contradictions, Uncovering New Dimensions." Globalizations 12, no. 4 (2015): 421433. Accessed February 1, 2016. doi:10.1080/14747731.2015.1041243.

WHO. "Food Security." Accessed March 5, 2016. http://www.who.int/trade/glossary/storyoz/en/.

Wittman, Hannah. "Reconnecting Agriculture \& the Environment: Food Sovereignty \& the Agrarian Basis of Ecological Citizenship." In Food Sovereignty: Reconnecting Food, Nature and Community, edited by Hannah Wittman, Annette Demarais, and Nettie Wiebe, 91-105. Black Point: Fernwood Publishing, 2010. 
Wittman, Hannah, Annette Desmarais, and Nettie Wiebe."The Origins and Potential of Food Sovereignty." In Food Sovereignty: Reconnecting Food, Nature and Community, edited by Hannah Wittman, Annette Demarais, and Nettie Wiebe, 114. Black Point: Fernwood Publishing, 2010.

World Bank. "Food Security." Accessed March 3, 2016. http://www.worldbank.org/en/topic/foodsecurity. 